\title{
Treatment of petroleum wastewater by conventional and new technologies - A review
}

\author{
Aljuboury D.A.D.A. ${ }^{1,}{ }^{*}$, Palaniandy P. ${ }^{1}$, Abdul Aziz H.B. ${ }^{1}$ and Feroz S. ${ }^{2}$ \\ ${ }^{1}$ School of Civil Engineering, Universiti Sains Malaysia, Malaysia \\ ${ }^{2}$ Caledonian College of Engineering, Oman \\ Received: 01/01/2017, Accepted: 29/08/2017, Available online: 19/10/2017 \\ "to whom all correspondence should be addressed: e-mail: msc.dheeaa@yahoo.com
}

\begin{abstract}
The objective of this study is to summarize studies and investigations and show a brief details of different technologies used for the treatment of petroleum wastewater. The wastewater from Petroleum industries and refineries mainly contains oil, organic matter and other compounds. The treatment of this wastewater can be carried out by physical, chemical and biological treatment processes. Treatment of petroleum wastewater has two stages, firstly, pre-treatment stage to reduce grease, oil and suspended materials. Secondly, an advanced treatment stage to degrade and decrease the pollutants to acceptable discharge values. Most studies are focused on degradation of some pollutants found in the petroleum wastewater such as organic materials, phenols, sulphides and ammonia.
\end{abstract}

Keywords: Petroleum wastewater treatment; Physical treatment processes; Chemical treatment processes; Biological treatment processes.

\section{Introduction}

The increasing global energy demand, which expected to be $44 \%$ over the next two decades (Doggett and Rascoe, 2009), makes the processing of petroleum, which is a complex mixture of organic liquids called crude oil and natural gas, and the generation of petroleum wastewater important issues. Industrial wastewater treatment is important study area in environmental engineering. The treatment of petroleum and petrochemical wastewater is widely studies area of research. These streams are difficult to treat due to large concentrations of oil.

The composition of effluent in refinery wastewater depends on the crude quality. It varies with the operating conditions (Benyahia et al., 2006). In the refinery, nonhydrocarbon substances are removed and the oil is broken down into its various components and blended into useful products. So, petroleum refineries produce large volumes of wastewater including oil well produced water brought to the surface during oil drilling, which often contain a recalcitrant compounds and rich in organic pollutants therefore cannot be treated easily and difficult to be treated biologically (Vendramel S. et al., 2015; Rasheed et al., 2011; Asatekin A. et al., 2009). Removal of pollutants produced by industrial plants is requirement for reuse of water and obtains to environmental standards (Farajnezhad and Gharbani, 2012). Petroleum wastewater are a major source of aquatic environmental pollution and are wastewater originating from industries primarily engaged in refining crude oil, manufacturing fuels and lubricants (Wake et al., 2005) and petrochemical intermediates (Harry et al., 1995). Coelho et al., (2006) reported that the volume of petroleum wastewater generated during processing is 0.4-1.6 times the amount of the crude oil processed. If the petroleum wastewater, which contained high organic matter, discharged into the aquatic environment, which required $2 \mathrm{mg} \mathrm{L}^{-1}$ from dissolved oxygen for normal life, results in decreased dissolved oxygen by the bacteria (Attiogbe et al., 2007). In anaerobic systems, the products of chemical and biochemical reactions produce displeasing colors and odors in water. So, the oxygen availability is important in water to reduce that (Attiogbe et al., 2007).

These effluents are composed of grease and petroleum compounds which consists of three main hydrocarbon groups; Paraffin [very few carbon atoms $\left(\mathrm{C}_{1}\right.$ to $\left.\mathrm{C}_{4}\right)$ such as Methane $\left(\mathrm{CH}_{4}\right)$, Ethane $\left(\mathrm{C}_{2} \mathrm{H}_{6}\right)$ and Propane $\left.\left(\mathrm{C}_{3} \mathrm{H}_{8}\right)\right]$, Naphthene [such as Cyclohexane $\left(\mathrm{C}_{6} \mathrm{H}_{12}\right)$ and Dimethyl Cyclopentane $\left(\mathrm{C}_{7} \mathrm{H}_{14}\right)$ ] and Aromatics [The more carbon atoms a hydrocarbon molecule such as Benzene $\left(\mathrm{C}_{6} \mathrm{H}_{6}\right)$, Toluene $\left(\mathrm{C}_{7} \mathrm{H}_{8}\right)$ and Xylene $\left(\mathrm{C}_{8} \mathrm{H}_{10}\right)$ (Wang B., 2015). In addition, Naphthenic acids (NAs) which are one class of compounds in wastewaters from petroleum industries that are known to cause toxic effects, and their removal from oilfield wastewater is an important challenge for remediation of large volumes of petrochemical effluents (Wang B., 2015). When a crude oil contains appreciable quantities of Sulphur, it is called sour crude. So, Sour water is a specific stream of petroleum refineries, which contains slowly biodegradable compounds and toxic substances (Coelho et al., 2006). Petroleum wastewater can vary greatly depending on the plant configuration, operation procedures and type of oil being processed (Saien and Nejati, 2007). 
The methods of petroleum wastewater treatment need to other steps to remove the organic matter, because they transfer of contaminants from one medium to another which include Chemical oxidation (Hu G et al., 2015), Biological techniques (Wang Y. et al., 2015), Coagulation (Abu hassan M.A., 2009; Farajnezhad and Gharbani, 2012; El-Naas et al., 2009) and Adsorption (Al Hashemi W., 2015). In addition, new technologies have also been reported such as Microwave-assisted catalytic wet air oxidation (Sun et al., 2008) and Membranes (Shariati et al., 2011; Yuliwati E. et al., 2011).

Diyauddeen et al., (2011) reviewed treatment technologies for petroleum refinery effluents (PRE) and showed that the petroleum refinery effluents treatment consisted of two main steps, which were pre-treatment and advanced treatment. The Biodegradation, Photo catalytic degradation, adsorption and other have been investigated with promising results. The important parameters in these treatment techniques were chemical oxygen demand (COD), biological oxygen demand (BOD), total petroleum hydrocarbon (TPH), oil and grease, sulphate and phenols. Because these methods have some disadvantages, the advanced oxidation processes (AOPs), in recent years, get more attention due to their capability of rapid degradation of recalcitrant pollutants in the aquatic environment by hydroxyl radical $(\cdot \mathrm{OH})$ (Aljuboury et al., 2015a; Kim J.L. et al., 2012), which has a high oxidation potential (estimated to be $+2.8 \mathrm{~V}$ ) relative to other oxidants (AlRasheed et al., 2005) and they have high efficiencies and less generation of sludge. In addition, they operate within a wide $\mathrm{pH}$ range. This review study focuses on studies and investigation on petroleum wastewater treatment.

\section{Wastewater and petroleum wastewater}

The refineries were classified into either hydro-skimming unit, which include a crude distillation unit, a desulphurising unit and a reforming unit, or a complex unit, which include a catalytic cracking unit with the hydroskimming refinery (Al Zarooni and Elshorbagy, 2006). In addition, Petrochemical plants were sometimes incorporated within the refinery complex (Wake et al., 2005). In general, the pollutants in wastewater can be divided into organic matter, inorganic matters which include nitrogen, phosphorus, ammonia and iron chlorides as well as heavy metals (Tengrui et al., 2007). The organic compounds and ammonia nitrogen considered the principal chemical characteristics of environmental concern in wastewater. The chemical oxygen demand (COD) and 5-day biochemical oxygen demand $\left(\mathrm{BOD}_{5}\right)$ are used as parameters to describe organic matter in wastewater.

\section{Petroleum wastewater generation in refineries}

Transforming crude oil into useful products such as Gasoline and kerosene was achieved by the numerous refinery configurations. During these processes, the petroleum wastewater was generated in the units such as Hydro-cracking, Hydro-cracker flare, Hydro-skimming, Hydro-skimmer flare, sourwater, Condensate, Condensate flare and the desalter. In addition, the main sources of total phenols in the received waste streams at the refinery wastewater treatment plant were the neutralized spent caustic (average $234 \mathrm{mg} / \mathrm{l}$ ) waste streams, the tank water drain (average $11.8 \mathrm{mg} / \mathrm{l}$ ) and the desalter effluent (average $1.4 \mathrm{mg} / \mathrm{I}$ ) (Al Hashemi W. et al., 2015). Other units not directly involved with processing; Sanitary, crude tank and laboratory water (Al Zarooni and Elshorbagy, 2006). The dominant pollutants in order of magnitude in petrochemical wastewater were normal-alkanes $\left(C_{10}-C_{21}\right)$, aromatics, and polycyclic hydrocarbons (Shokrollahzadeh et al., 2008)

\section{Petroleum wastewater characteristics}

The different types of organic materials typically found in the petroleum as shown in Table 1. Due to the petroleum wastewater contented high polycyclic aromatics, which were very toxic as well as a wide range of contaminants at varied concentrations, it was considered hazardous pollutants on the environment (Mrayyana and Battikhi, 2005; Wake et al., 2005). The identification of the organic pollutants in petroleum refinery wastewater in some refineries showed that the major compounds were different fractions of petroleum aliphatic hydrocarbons (up to $C_{10}$ ) and the well-known aromatic compounds such as benzene, toluene and ethyl-benzene (Saien et al., 2007). Seif et al., (2001) showed that the maximum removal for COD and BOD were around 1400-1500 mg/l and 25-30 $\mathrm{mg} / \mathrm{l}$, respectively from different sources of petrochemical wastewater by using physical treatment and concluded that separation and individual treatment for each source was a good alternative against treatment full quantity after mixing of different sources.

The petroleum wastewater are complex matrices of organic pollutants as shown in Table 1 and the most of them contented Oil and grease, which clog drain pipes and causing unpleasant odors and corroding as well as are sticky (Chen et al., 1999; Xu and Zhu, 2004), phenolic compounds, which threat the environment due to their extreme toxicity and ability to remain for long periods (Kavitha and Palanivelu, 2004; Abdelwahab et al., 2009; Lathasree et al., 2004; Pardeshi and Patil, 2008; Yang et al., 2008), and the nitrogen and sulphur components, which are represented in the form of ammonia and hydrogen sulphide $\left(\mathrm{H}_{2} \mathrm{~S}\right)$, respectively (Altas and Buyukgungor, 2008). In addition, Naphthenic acids (NAs) are one class of compounds in wastewaters from petroleum industries that are known to cause toxic effects, and their removal from oilfield wastewater is an important challenge for remediation of large volumes of petrochemical effluents (Wang B. et al., 2015). Wang B. et al. (2015) reported that the percentage of aromatic naphthenic acids (NAs) in total naphthenic acids (NAs) was estimated to be $2.1-8.8 \%$ in a refinery wastewater treatment plant. 
Table 1. Characteristics of petroleum wastewater reported by various researchers:

\begin{tabular}{|c|c|c|c|c|c|c|c|c|c|c|c|c|c|}
\hline \multirow[b]{2}{*}{ The parameters } & \multicolumn{13}{|c|}{ The reference } \\
\hline & $\begin{array}{c}\text { Vendrame } \\
\text { et al., } \\
\text { (2015) }\end{array}$ & $\begin{array}{l}\text { Aljuboury et } \\
\text { al., (2014b) }\end{array}$ & $\begin{array}{l}\text { Saber } \\
\text { et al., } \\
(2014)\end{array}$ & $\begin{array}{l}\text { Gasim } \\
\text { et al., } \\
(2012) \\
\end{array}$ & $\begin{array}{l}\text { Tony } \\
\text { et al., } \\
\text { (2012) } \\
\end{array}$ & $\begin{array}{l}\text { Hasan } \\
\text { et al., } \\
(2012) \\
\end{array}$ & $\begin{array}{c}\text { Farajnezhed } \\
\text { et al., } \\
\text { (2012) }\end{array}$ & $\begin{array}{c}\text { Abdelwahab } \\
\text { et al., } \\
\text { (2009) }\end{array}$ & $\begin{array}{l}\text { El-Nass } \\
\text { et al., } \\
\text { (2009) }\end{array}$ & $\begin{array}{c}\text { Atlas et } \\
\text { al., (2008) }\end{array}$ & $\begin{array}{l}\text { Dincer } \\
\text { et al., } \\
\text { (2008) }\end{array}$ & $\begin{array}{c}\text { Zenga et al., } \\
\text { (2007) }\end{array}$ & $\begin{array}{c}\text { Demicrci } \\
\text { et al., } \\
(1998)\end{array}$ \\
\hline $\mathrm{pH}$ & 8.3 & $6.5-9.5$ & 6.7 & 8.48 & 7.6 & 7.0 & 7.5 & 8 & 9.5 & $7.19-9.22$ & 2.5 & $6.5-6.8$ & $6.5-8.5$ \\
\hline COD (mg/L) & 1250 & $550-1600$ & 450 & 7896 & 364 & 1343 & 1120 & $80-120$ & 4050 & 220 & 21000 & $500-1000$ & 800 \\
\hline BOD (mg/L) & - & & 174 & 3378 & & 846 & - & 40.25 & - & & 8000 & & 350 \\
\hline $\mathrm{TSS}(\mathrm{mg} / \mathrm{L})$ & 150 & & 150 & - & 105 & 74 & 110 & 22.8 & 80 & & 2580 & $90-300$ & 100 \\
\hline Ammonia(mg/L) & - & & & 13.5 & & & - & - & - & & 69 & & \\
\hline Phenols (mg/L) & - & & & - & & & - & 13 & - & & & $10-20$ & 8 \\
\hline Sulphides(mg/L) & - & & & - & & & - & - & 1222 & 20 & & $15-30$ & 17 \\
\hline Turbidity(NTU) & & & & & 42 & 83 & & & & & & $150-350$ & \\
\hline Oil \& grease (mg/L) & & & 870 & & 946 & 240 & & & & & 1140 & $400-1000$ & 3000 \\
\hline TDS (mg/L) & & $1200-1500$ & & & & & & & & & 37000 & $3000-5000$ & \\
\hline TOC (mg/L) & & $220-265$ & 119 & & & 398 & & & & & & & \\
\hline
\end{tabular}


The following general conclusions can be drawn from these Characteristics of petroleum wastewater reported by various researchers as shown in Table 1:

- The composition of effluent in petroleum wastewater depends on the crude quality, the operating conditions and the sources of wastewater pollutants. So, the big difference was shown in specification of wastewater among the investigated studies and a wide variety of pollutants at varying concentrations.

- The most compounds in petroleum wastewater were dissolved and dispersed oil, which are a mixture of hydrocarbons (benzene, ethylbenzene, xylenes, toluene, polyaromatic, phenol and hydrocarbons (PAH)). In addition, the dissolved formation minerals are inorganic compounds, which include heavy metals.
- $\quad$ The average sulphide concentration was about 20 $\mathrm{mg} / \mathrm{L}$, But it high concentration in sour water stream (SWS), which has complex chemical compositions such as oil, phenols, sulphides, mercaptans, ammonia, cyanides and other micropollutants. So, El-Naas et al., (2009) reported that the sulphide concentration was $1222 \mathrm{mg} / \mathrm{L}$.

Various environmental protection agencies set maximum limits of discharge for each component of the waste as shown in Table 2 to protect environment from the hazardous composition in petroleum wastewater. The fuel additives, which were carcinogenic such as dichloroethane (DCE), Dichloromethane (DCM) and t-butyl methyl ether (tBME), were considered the most of un-degraded total petroleum hydrocarbon (Diya'uddeen, B. H., 2011; Squillance et al., 1996).

Table 2. Minimum standard discharge limits for refinery effluents

\begin{tabular}{|c|c|c|c|c|c|c|c|c|c|}
\hline \multirow{2}{*}{ pH } & \multicolumn{7}{|c|}{ Composition (mg/L) } & Ref. \\
\cline { 2 - 9 } & COD & BOD & TDS & SS & TOC & Ammonia & Phenols & Sulphides & Ma et al., (2009) \\
\hline $6-9$ & 100 & $10-15$ & - & 70 & & 15 & - & - & $\begin{array}{c}\text { Environmental } \\
\text { Health Safety } \\
\text { Guidelines (2009) }\end{array}$ \\
\hline $6-9$ & 150 & 30 & - & 30 & & - & - & $1.0 \begin{array}{c}\text { Aljuboury et al., } \\
\text { (2015a) }\end{array}$ \\
\hline 6
\end{tabular}

\section{Current petroleum wastewater treatment techniques}

The petroleum wastewater treatments are classified into three types; physical, chemical and biological. However, the treatment required a typical application of the integrated system due to the complexity of characteristics of petroleum wastewater. Thus, the conventional treatment methods need multistage process treatment. The first stage consisted of pre-treatment, which includes mechanical and physicochemical treatments followed by the second stage which is the advanced treatment of the pretreated wastewater. Based on the literature review conducted, the techniques and methods for petroleum wastewater treatment included physical, chemical, biological treatment processing.

\subsection{Physical treatment}

Physical treatment methods include processes where no gross chemical or biological changes are carried out and strictly physical phenomena are used to improve or treat the wastewater. Examples would be coarse screening to remove larger entrained objects and sedimentation. The presence of sulphide and salts could inhibit biological operation in excess of $20 \mathrm{mg} \mathrm{L}^{-1}$ (Altaş and Büyükgüngör, 2008). Thus, the physical treatment system is a primary treatment step, which is essential to remove or separate suspended solids (SS), immiscible liquids, solid particles, suspended substances (Renault et al., 2009) from petroleum wastewater by using sedimentation, coagulation and flocculation and prolonged use of the secondary treatment unit. Most physical treatment techniques are considered as conventional methods.

Nowadays, physical technologies such as sedimentation are used prior to biological treatment in order to remove suspended solids. The sedimentation treatment, which is used to separate oil from water, is mechanically achieved by gravity in API separators or separation tanks. Coagulation process was used to remove turbidity and organic load abatement. However, physical processes were relatively ineffective for the treatment of petroleum wastewater because of its complexity and therefore, other processes might be used for pretreatment.

As shown in Table 3, Wang et al. (2015) reported that the maximum reductions for total naphthenic acids (NAs) and aromatic naphthenic acids by the physicochemical processes were $16 \%$ and $24 \%$, respectively in a refinery wastewater while they were $65 \%$ and $86 \%$, respectively, by the biological processes.

\subsection{Membrane}

Membranes could be generally classified into biological membranes (Malamis et al., 2015; Razavi and Miri, 2015) and synthetic membranes. Membrane technologies such as electrodialysis and ultra-filtration are being applied increasingly. Membrane separation was found useful in treating organic matter and more acceptable and economic than other physical treatment techniques (Jyoti et al., 2013; Kulkarni and Goswami, 2014). 
Table 3. Overview of work done in the area of physicochemical treatment applications to treat the petroleum wastewater reported by various researchers

\begin{tabular}{|c|c|c|c|c|c|}
\hline No. & The method applied & $\begin{array}{c}\text { The } \\
\text { wastewater } \\
\text { type }\end{array}$ & Removed pollutants & $\begin{array}{l}\text { Max. Removal } \\
\text { efficiency (\%) }\end{array}$ & Ref. \\
\hline \multirow[b]{2}{*}{1} & \multirow{2}{*}{ The physicochemical processes } & \multirow{2}{*}{$\begin{array}{l}\text { A refinery } \\
\text { wastewater }\end{array}$} & $\begin{array}{c}\text { Total naphthenic acids } \\
\text { (NAs) }\end{array}$ & 16 & \multirow{2}{*}{ Wang et al., (2015) } \\
\hline & & & $\begin{array}{c}\text { Aromatic naphthenic } \\
\text { acids }\end{array}$ & 24 & \\
\hline 2 & $\begin{array}{l}\text { An immersed membrane } \\
\text { process }\end{array}$ & $\begin{array}{l}\text { Petroleum } \\
\text { refinery } \\
\text { wastewater }\end{array}$ & wastewater oil content & 69 & Al-Malack (2016) \\
\hline \multirow[b]{2}{*}{3} & \multirow[b]{2}{*}{ Membrane bioreactor (MBR) } & \multirow{2}{*}{$\begin{array}{c}\text { Petrochemical } \\
\text { wastewater }\end{array}$} & Heavy metals & 70 & \multirow{2}{*}{ Malamis et al., (2015) } \\
\hline & & & Iron & 75 & \\
\hline 4 & $\begin{array}{c}\text { Nanocomposite membrane } \\
\text { with the multi-walled carbon } \\
\text { nanotube (MWCNT) } \\
\text { incorporated in Polyvinylidene } \\
\text { fluoride (PVDF) matrix }\end{array}$ & $\begin{array}{c}\text { refinery } \\
\text { wastewater }\end{array}$ & Oil & & $\begin{array}{l}\text { Moslehyani et al., } \\
\text { (2015) }\end{array}$ \\
\hline 5 & $\begin{array}{l}\text { A cross-flow membrane } \\
\text { bioreactor (CF-MBR) }\end{array}$ & $\begin{array}{l}\text { Petroleum } \\
\text { wastewater }\end{array}$ & COD & 93 & $\begin{array}{c}\text { Rahman and Al-Malack } \\
(2006)\end{array}$ \\
\hline \multirow{5}{*}{6} & \multirow{5}{*}{$\begin{array}{c}\text { The hollow-fiber membrane } \\
\text { bioreactor (HF-MBR) }\end{array}$} & \multirow{5}{*}{$\begin{array}{l}\text { Real petroleum } \\
\text { refinery } \\
\text { wastewater }\end{array}$} & COD & 82 & \multirow{5}{*}{ Razavi and Miri (2015) } \\
\hline & & & $\mathrm{BOD}_{5}$ & 89 & \\
\hline & & & TSS & 98 & \\
\hline & & & VSS & 99 & \\
\hline & & & Turbidity & 98 & \\
\hline 7 & $\begin{array}{l}\text { Membrane sequencing batch } \\
\text { reactor }\end{array}$ & $\begin{array}{l}\text { A synthetic } \\
\text { petroleum } \\
\text { wastewater }\end{array}$ & Hydrocarbon pollutants & 97 & Shariati et al., (2011) \\
\hline 8 & Ultra-filtration (UF) membranes & $\begin{array}{c}\text { Refinery } \\
\text { wastewater }\end{array}$ & COD & 44 & $\begin{array}{l}\text { Asatekin and Mayes } \\
\text { (2009) }\end{array}$ \\
\hline 9 & $\begin{array}{c}\text { Poly aluminum chloride and } \\
\text { ferric chloride for coagulation } \\
\text { treatment }\end{array}$ & $\begin{array}{l}\text { Petroleum } \\
\text { wastewater }\end{array}$ & COD & 58 & $\begin{array}{c}\text { Farajnezhad \& } \\
\text { Gharbani (2012) }\end{array}$ \\
\hline 10 & $\begin{array}{c}\text { Poly-zinc silicate (PZSS) and } \\
\text { anion polyacrylamide (A-PAM) } \\
\text { for coagulation /flocculation } \\
\text { treatment. }\end{array}$ & $\begin{array}{c}\text { Heavy oil } \\
\text { wastewater }\end{array}$ & Oil & 99 & Zeng et al. (2007) \\
\hline \multirow[b]{2}{*}{11} & \multirow[b]{2}{*}{ Subsequent coagulation $/ \mathrm{H}_{2} \mathrm{O}_{2}$} & \multirow{2}{*}{$\begin{array}{l}\text { Petroleum } \\
\text { refinery } \\
\text { wastewater }\end{array}$} & COD & 58 & \multirow{2}{*}{$\begin{array}{l}\text { Wagner and Nicell } \\
\qquad(2001)\end{array}$} \\
\hline & & & $\mathrm{BOD}_{5}$ & 78 & \\
\hline \multirow[b]{2}{*}{12} & Coagulation by alum & \multirow{2}{*}{$\begin{array}{l}\text { petrochemical } \\
\text { wastewater. }\end{array}$} & COD & 61 & \multirow[b]{2}{*}{ Altaher et al., (2011) } \\
\hline & $\begin{array}{l}\text { Coagulation by ferric chloride } \\
\qquad\left(\mathrm{FeCl}_{3}\right)\end{array}$ & & COD & 52 & \\
\hline 13 & Electro-coagulation & $\begin{array}{l}\text { Petrochemical } \\
\text { wastewater }\end{array}$ & Phenol & 100 & $\begin{array}{c}\text { El-Ashtoukhy et al., } \\
\text { (2013) }\end{array}$ \\
\hline 14 & $\begin{array}{c}\text { A cell with horizontally oriented } \\
\text { aluminum cathode and a } \\
\text { horizontal aluminum screen } \\
\text { anode at high current density }\end{array}$ & $\begin{array}{c}\text { Oil refinery } \\
\text { waste effluent }\end{array}$ & Phenol & 97 & $\begin{array}{l}\text { Abdelwahab et al., } \\
\text { (2009) }\end{array}$ \\
\hline 15 & Electro-coagulation & $\begin{array}{l}\text { Petroleum } \\
\text { wastewater }\end{array}$ & Phenol & 51 & $\begin{array}{c}\text { Jafarzadeh et al., } \\
\text { (2011) }\end{array}$ \\
\hline 16 & adsorption by organoclay & $\begin{array}{l}\text { Petroleum } \\
\text { wastewater }\end{array}$ & organic substances & 62 & $\begin{array}{c}\text { Cavalcanti et al., } \\
\text { (2012) }\end{array}$ \\
\hline 17 & An activated carbon adsorption & $\begin{array}{l}\text { Petroleum } \\
\text { wastewater }\end{array}$ & COD & 60 & El-Naas et al., (2009) \\
\hline 18 & $\begin{array}{c}\text { A microwave-assisted catalytic } \\
\text { wet air oxidation process. }\end{array}$ & $\begin{array}{l}\text { Petroleum } \\
\text { wastewater }\end{array}$ & COD & 90 & Sun et al., (2008) \\
\hline \multirow{4}{*}{19} & \multirow{4}{*}{ The $\mathrm{O}_{3} / \mathrm{UV} / \mathrm{TiO}_{2}$ process. } & \multirow{4}{*}{$\begin{array}{l}\text { Petroleum } \\
\text { wastewater }\end{array}$} & Phenol & 99.9 & \multirow{4}{*}{ Corrêa et al., (2010) } \\
\hline & & & Sulfide & 97.2 & \\
\hline & & & COD & 89.2 & \\
\hline & & & Oil & 98.2 & \\
\hline \multirow[b]{2}{*}{20} & \multirow{2}{*}{$\begin{array}{c}\text { Partial precipitant }\left[\mathrm{FeCl}_{3} \cdot 6 \mathrm{H}_{2} \mathrm{O}\right. \\
\left.\text { and } \mathrm{FeSO} \mathrm{SO}_{4} \cdot 7 \mathrm{H}_{2} \mathrm{O}\right] \text { and coagulant } \\
\text { aids }\left[\mathrm{Ca}(\mathrm{OH})_{2} \text { and } \mathrm{CaCO}_{3}\right]\end{array}$} & \multirow{2}{*}{$\begin{array}{c}\text { Petroleum } \\
\text { refinery } \\
\text { wastewater }\end{array}$} & COD & 75 & \multirow{2}{*}{$\begin{array}{l}\text { Altaş and Büyükgüngör } \\
\text { (2008) }\end{array}$} \\
\hline & & & Sulfide & 99 & \\
\hline
\end{tabular}


Depending on the pore size, they can be classified as ultrafiltration (UF) (Asatekin \& Mayes, 2009), microfiltration (MF) (Zhong et al., 2003), nanofiltration (NF) (Moslehyani et al., 2015), and reverse osmosis (RO) membranes (Li et al., 2009). Al-Malack (2016) reported that an application of immersed membrane process was dramatically affected by wastewater oil content and permeate flux values in treating petroleum refinery wastewater. The maximum allowable trans-membrane pressure (TMP) reached a value of 9 Pascal with the increase in permeate flux and oil content, which result in more backwashing and cleaning cycles. Trans-membrane pressure (TMP) is pressure difference between feed and permeate stream.

As shown in Table 3, Malamis et al., (2015) showed that membrane bioreactor (MBR) removed heavy metals from petrochemical wastewater in different removal percentages, which range from $40 \%$ to $70 \%$, and only iron removal was the maximum removal in this process, being higher than $70 \%$. Moslehyani et al., (2015) indicated that the best nanocomposite membrane was nanocomposite membrane with the multi-walled carbon nanotube (MWCNT) incorporated in Polyvinylidene fluoride (PVDF) matrix for the filtration purposes because it removed all pollutants from refinery wastewater and it was the excellent anti-fouling property.

The principles of cross-flow filtration were used in nanofiltration, ultrafiltration, microfiltration and reverse osmosis. Rahman and Al-Malack, (2006) reported that the using of a cross-flow membrane bioreactor (CF-MBR) to treat the petroleum wastewater achieved a COD removal efficiency of more than $93 \%$ at mixed liquor suspended solids (MLSS) concentrations of 5000 and $3000 \mathrm{mg} \mathrm{L}^{-1}$.

Razavi and Miri, (2015) showed that the average removal efficiencies of $\mathrm{COD}, \mathrm{BOD}_{5}$, TSS, VSS, and turbidity from real petroleum refinery wastewater by using the hollow-fiber membrane bioreactor (HF-MBR) were attained 82\%, 89\%, 98\%, 99\%, and 98\%, respectively. Yuliwati et al., (2011) proved that interactions between the membrane surface and suspended solid constituents in refinery wastewater strongly influenced the membrane fouling in polyvinylidene fluoride (PVDF) hollow fiber membranes.

Shariati et al., (2011) reported that removal efficiencies higher than $97 \%$ were found for the three model hydrocarbon pollutants by using membrane sequencing batch reactors at 8,16 , and $24 \mathrm{~h}$ for the treatment of a synthetic petroleum wastewater. Particle size distribution (PSD) and microscopic analysis showed the reduction in the protozoan populations in the activated sludge with decreasing the time. The rate of membrane fouling was found to increase with decreasing hydraulic retention times (HRT). Ultrafiltration (UF) is very promising for their treatment to remove oil, but has been limited by economic obstacles due to severe membrane fouling (Asatekin and Mayes, 2009). Asatekin and Mayes (2009) reported that the COD removal values were substantially lower, between 41 and $44 \%$, by using Ultra-filtration (UF) membranes for refinery wastewater treatment due to higher contents of dissolved organics. Hua et al., (2007) reported that the accumulation volume of permeation was significantly affected by the trans-membrane pressure, indicating the model was reliable.

Membrane technologies, particularly reverse osmosis (RO), are relatively new processes that seem to be a more effective alternative than conventional methods for petroleum wastewater treatment. The process involves separating two solutions at different concentrations by a semipermeable membrane. Naturally, water would flow from the less concentrated solution to the more concentrated solution. However, the membrane processes have some major disadvantages such as; the generation of a great amount of residual concentrate and membrane fouling. Membrane fouling needs chemical cleaning of membranes or wide pretreatment and leads to a little lifetime of the membranes and decreases efficiency of the process (Li et al., 2009).

\subsection{Coagulation/Flocculation}

Chemical coagulation process is an important and conventional method for wastewater treatment to reduce or remove turbidity, color, COD and TSS (Farajnezhad and Gharbani, 2012). It is an efficient pretreatment process when used before biological or membrane treatment process or used as a final polishing treatment in order to reduce or eliminate non-biodegradable organic matter in petroleum wastewater (Farajnezhad and Gharbani, 2012). Coagulation or flocculation process was conducted for the treatment of a petroleum wastewater to achieve maximum removal of COD, TP, and TSS.

However, the coagulation is considered inappropriate for a full treatment of wastewater because of its limited efficiency to remove the organic matter (Hassan et al., 2009). Farajnezhad and Gharbani, (2012) used poly aluminum chloride and ferric chloride for coagulation treatment of wastewater in the petroleum industry. They observed that poly aluminum chloride was more effective. The variation of $\mathrm{pH}$ has an insignificant effect on the color removal of petroleum wastewater. The efficiency of COD removal from petroleum wastewater depended on petroleum wastewater characteristics and coagulant species, which can be usually inorganic metal salts such as aluminum sulfate (alum), ferrous sulfate, ferric chloride and ferric chloro-sulfate, and coagulant dosage.

Altaş and Büyükgüngör, (2008) showed that the COD removal efficiencies from petroleum refinery wastewater varied between $45-75 \%$ by using partial precipitant $\left[\mathrm{FeCl}_{3} \cdot 6 \mathrm{H}_{2} \mathrm{O}\right.$ and $\left.\mathrm{FeSO}_{4} \cdot 7 \mathrm{H}_{2} \mathrm{O}\right]$ and coagulant aids $\left[\mathrm{Ca}(\mathrm{OH})_{2}\right.$ and $\mathrm{CaCO}_{3}$ ] at different $\mathrm{pH}$ values and removal efficiencies of sulfide were $96-99 \%$. The COD removal efficiencies of $\mathrm{Fe}^{3+}$ and $\mathrm{Fe}^{2+}$ ions together with coagulant aids $\left[\mathrm{Ca}(\mathrm{OH})_{2}\right]$, were $50-80$ and $32-50 \%$, respectively.

Several investigations stated that coagulation favored removal of organic compounds in petroleum wastewater. Zeng et al., (2007) showed that more than $99 \%$ of the oil was removed from heavy oil wastewater at $40 \mathrm{~min}$ and $\mathrm{pH}$ 6.5-9.5 by the using Poly-zinc silicate (PZSS) and anion polyacrylamide (A-PAM) for coagulation /flocculation of oil and suspended solids. The Poly-zinc silicate (PZSS) was 
more efficient than poly-ferric sulfate (PFS) and polyaluminum chloride (PAC) (Zeng et al., 2007). Another work by Demirci et al., (1998) indicated that the coagulant aids, coagulants and Turkish clay was used to treat the petroleum wastewater. The efficiency of Turkish clay was less than that obtained with polymeric materials. In addition, Dialynas et al., (2008) reported that ferric chloride increased floc size and decreased sedimentation time more than alum. Thus, ferric chloride was more efficient than alum and iron salts were more efficient than aluminum or lime addition in removing organic compounds of wastewater. Wagner and Nicell (2001) revealed that subsequent coagulation $/ \mathrm{H}_{2} \mathrm{O}_{2}$ removed $58 \%$ of $\mathrm{COD}$ and $78 \%$ of $\mathrm{BOD}_{5}$ from petroleum refinery wastewater. Altaher et al., (2011) used coagulation for pre-treatment of petroleum and petrochemical wastewater. Their results indicated that the alum was more removal efficiency of COD than ferric chloride $\left(\mathrm{FeCl}_{3}\right)$ and promoted turbidity removal when the $\mathrm{pH}$ increased from an acidic range to an alkaline range. However, the disadvantage of alum was its hazardous nature. They also reported that ferric chloride had superior efficiency compared with other coagulants with an efficient dose of $800 \mathrm{mg} \mathrm{L}^{-1}$.

\subsection{Electro-Coagulation}

The treatment process is found to be largely affected by the current density, the type of anode and cathode, and the initial composition of the wastewater. The rate of electrocoagulation improved with the increasing number of screens per array and with reducing the concentration of phenol (Abdelwahab et al., 2009). El-Ashtoukhy et al., (2013) obtained $100 \%$ removal of phenol in 2 hours from petrochemical wastewater by electrocoagulation using a fixed bed electrochemical reactor.

The type of anode and cathode has an important role in this process, for example. Farajnezhad and Gharbani (2012) indicated that the using poly aluminum chloride was more removal efficiency than the using ferric chloride in petrochemical wastewater treatment. Another work by ElNaas et al., (2009) showed that the utilization of aluminum, as anode and cathode, in batch electrocoagulation experiments was by far the most efficient arrangement comparing with stainless steel and iron in the reduction of COD and sulfate from petroleum wastewater. In addition, Abdelwahab et al., (2009) reported that remarkable removal of $97 \%$ of phenol from the oil refinery waste effluent after $2 \mathrm{~h}$ was achieved by using a cell with horizontally oriented aluminum cathode and a horizontal aluminum screen anode at high current density and solution pH 7 while Yavuz et al., (2010) indicated that the electrocoagulation was found to be ineffective in the treatment of petroleum refinery wastewater due to the high amount of soluble organic pollutants and low amount of suspended solids contained in PRW.

Jafarzadeh et al., (2011) carried out an investigation on the electrocoagulation method for treatment of petroleum effluent and obtained the phenol removal efficiency of $51 \%$ was obtained at $75 \mathrm{~min}$ operating time.

\subsection{Adsorption}

Advantages of adsorption were low cost, simplicity, and adaptability (Kulkarni \& Goswami, 2013, 2014). A recent work by Cavalcanti et al. (2012) reviewed investigations on adsorption by organoclay for removal of effluent from the petroleum wastewater. They observed that organophilic clays were effective as adsorbents for the removal of organic substances with high toxicity, such as phenols and BTEX compounds.

Adsorption technology mainly refers to activated carbon adsorption. It is commonly utilized for organic compounds, ammonium and toxicity characteristics in treatment of petroleum wastewater (Lorenc and Gryglewicz, 2007). An addition of sorbent and coupling the activated sludge to form a biologically activated carbon system improve the treatment through adsorption.

An activated carbon adsorption is effective in removing organic compounds residual after biological treatment. In addition, low molecular weight pollutants are specially adsorbed (Lorenc and Gryglewicz, 2007). This method is limited by high consumption of activated carbon or the requirement for frequent regeneration of columns (Renou et al., 2008). El-Naas et al. (2009) achieved 30\% COD reduction at the ambient temperature, whereas at $60{ }^{\circ} \mathrm{C}$ $53 \%$ COD reduction was reached.

\subsection{Physical-chemical treatment}

The Physical-chemical treatment process combines physical treatment techniques (such as absorption and filtration) and chemical treatment techniques (such as oxidation and ozonation) to treat industrial and commercial wastewater (El-Naas et al., 2009). After the mechanical step, the physiochemical step agglomerates small-sized suspended solids into large-sized particles to ease removal by filtration, floatation, and sedimentation (El-Naas et al., 2009).

AOPs are defined as the methods that produce hydroxyl radicals in adequate amounts to be capable of degrading majority of the recalcitrant contaminants existing in the discharge water (De Morais and Zamora, 2005). Treatment of petroleum wastewater has been conducted by a wide range of technologies and approaches.

In recent years, the strict discharge standards in most countries are set to fully reduce impacts on the environment. Many conventional technologies are not used for some recalcitrant and persistent compounds because of the poor performance of these processes with these compounds. The combination of suitable treatment processes can provide effective treatment for these compounds in the petroleum wastewater. Among chemical methods, AOPs present the greatest solution (Gogate and Pandit, 2004) and are outstanding alternative for the treatment of petroleum wastewater due to their enormous potential to reduce a substantial COD, improve biodegradability and degrade a wide variety of refractory compounds from petroleum wastewater (Hermosilla et al., 2009). In addition, AOPs can also achieve a considerably high efficiency of the removal of organic compounds based on the high oxidative power of the hydroxyl radicals (Gogate and Pandit, 2004) and convert them to carbon 
dioxide and water or to other byproducts (Hermosilla et al., 2009). This advantage is considered the main advantage of the AOPs because they destroy the pollutants by hydroxyl radicals and convert them into $\mathrm{CO}_{2}$ and water rather than transferring them from one phase to another.

However, most limits of application of AOPs in wastewater treatment plants in refineries are a high energy consumption and the possibility of producing critical intermediates (Gogate and Pandit, 2004).

\subsection{Chemical treatment}

Chemical treatment consists of using some chemical reaction or reactions to improve the water quality. A chemical process commonly used in many industrial wastewater treatment operations is neutralization. Neutralization consists of the addition of acid or base to adjust $\mathrm{pH}$ levels back to neutrality. Since lime is a base it is sometimes used in the neutralization of acid wastes.

As shown in Table 3, a previous work by Sun et al. (2008) reported that using a microwave-assisted catalytic wet air oxidation process achieved more than $90 \%$ of COD removal and increase $\mathrm{BOD}_{5} / \mathrm{COD}$ ratio from 0.04 to 0.47 at $30 \mathrm{~min}$ to treat petroleum wastewater at $150{ }^{\circ} \mathrm{C}$ with $0.8 \mathrm{MPa}$ pressure. Although high efficiency was reached, a $150{ }^{\circ} \mathrm{C}$ is not promising due to the high energy cost.

\subsection{Biological treatment}

Use microorganisms, mostly bacteria, in the biochemical decomposition of wastewaters to stable end products. More microorganisms, or sludges, are formed and a portion of the waste is converted to carbon dioxide, water and other end products (Zhao et al., 2006). The petroleum wastewater was treated by various biological methods successfully (Manyuchi and Ketiwa, 2013; Melamane et al., 2007; Pal and Vimala, 2012) such as activated sludge reactors or biofilm-based reactor to remove the organic pollutants. The biological oxidation processes depend on the compositions of the petroleum wastewater. However, these processes have some disadvantages such as the extreme sludge production, and low capacity to COD removals (Jou and Huang, 2003). Generally, biological treatment methods can be divided into aerobic and anaerobic methods, based on availability of dissolved oxygen (Zhao et al., 2006). In anaerobic systems, the products of chemical and biochemical reactions produce displeasing colors and odors in water. Thus, the oxygen availability was important in water to reduce displeasing colors and odors (Attiogbe et al., 2007).

Table 4. Overview of work done in the area of Biological treatment applications to treat the petroleum wastewater reported by various researchers:

\begin{tabular}{|c|c|c|c|c|c|}
\hline No. & The method applied & $\begin{array}{c}\text { The wastewater } \\
\text { type }\end{array}$ & $\begin{array}{l}\text { Removed } \\
\text { pollutants }\end{array}$ & $\begin{array}{l}\text { Max. Removal } \\
\text { efficiency (\%) }\end{array}$ & Reference \\
\hline \multirow[b]{2}{*}{1} & \multirow{2}{*}{$\begin{array}{l}\text { The reactor immobilized } \\
\text { with microorganisms }\end{array}$} & \multirow{2}{*}{$\begin{array}{l}\text { Petroleum } \\
\text { refinery } \\
\text { wastewater }\end{array}$} & TOC & 78 & \multirow[b]{2}{*}{ Zhao et al., (2006) } \\
\hline & & & Oil & 94 & \\
\hline 2 & $\begin{array}{c}\text { The aerobic biological } \\
\text { process }\end{array}$ & $\begin{array}{c}\text { Petroleum } \\
\text { wastewater }\end{array}$ & COD & 86 & $\begin{array}{c}\text { Satyawali and } \\
\text { Balakrishnan (2008) }\end{array}$ \\
\hline 3 & $\begin{array}{l}\text { The anaerobic treatment } \\
\text { process (a UASB reactor) }\end{array}$ & $\begin{array}{l}\text { Petroleum } \\
\text { refinery } \\
\text { wastewater }\end{array}$ & COD & 82 & Gasim et al., (2013) \\
\hline \multirow{2}{*}{4} & \multirow{2}{*}{$\begin{array}{l}\text { The up-flow anaerobic } \\
\text { sludge bed (UASB) reactor }\end{array}$} & \multirow{2}{*}{$\begin{array}{c}\text { Heavy oil refinery } \\
\text { wastewater }\end{array}$} & COD & 70 & \multirow{2}{*}{ Wang et al., (2006) } \\
\hline & & & oil & 72 & \\
\hline \multirow[b]{3}{*}{5} & \multirow{3}{*}{$\begin{array}{l}\text { The up-flow anaerobic } \\
\text { sludge blanket (UASB) } \\
\text { reactor and a two-stage } \\
\text { biological aerated filter } \\
\text { (BAF) system }\end{array}$} & \multirow[b]{3}{*}{$\begin{array}{c}\text { Heavy oil } \\
\text { wastewater }\end{array}$} & $\mathrm{NH}_{3}-\mathrm{N}$ & 90.2 & \multirow[b]{3}{*}{ Zou, (2015) } \\
\hline & & & COD & 90.8 & \\
\hline & & & oil & 86.5 & \\
\hline 6 & $\begin{array}{l}\text { A combined UASB and } \\
\text { anaerobic packed-bed } \\
\text { biofilm reactor }\end{array}$ & $\begin{array}{l}\text { Petroleum } \\
\text { wastewater }\end{array}$ & COD & 81.07 & Nasirpour et al., (2015) \\
\hline 7 & $\begin{array}{c}\text { The activated sludge } \\
\text { system }\end{array}$ & $\begin{array}{l}\text { Petroleum } \\
\text { wastewater }\end{array}$ & $\begin{array}{l}\text { Naphthenic } \\
\text { Acids (NAs) }\end{array}$ & 73 & Wang et al., (2015) \\
\hline 8 & $\begin{array}{c}\text { The sequencing batch } \\
\text { reactor system }\end{array}$ & $\begin{array}{l}\text { Petroleum } \\
\text { wastewater }\end{array}$ & Phenols & 98 & Al Hashemi et al., (2015) \\
\hline \multirow[b]{2}{*}{9} & \multirow{2}{*}{$\begin{array}{c}\text { Anaerobic submerged } \\
\text { fixed-bed reactor (ASFBR) }\end{array}$} & \multirow{2}{*}{$\begin{array}{l}\text { Petroleum } \\
\text { wastewater }\end{array}$} & COD & 91 & \multirow{2}{*}{ (Vendramel et al., 2015) } \\
\hline & & & TSS & 92 & \\
\hline
\end{tabular}

\subsection{Aerobic biological processes}

The aerobic biological process converts the organic compounds and recalcitrant components in wastewater into $\mathrm{CO}_{2}$ and water and solid biological products. As shown in Table 4, Zhao et al,. (2006) showed that the reactor immobilized with microorganisms achieved degradation efficiencies of $78 \%$ TOC removal and $94 \%$ oil removal from 
petroleum refinery wastewater. The aerobic biological process has shown improved COD removal by Satyawali and Balakrishnan, (2008). In addition, they reported it had a higher tolerance to toxic and organic shock loads and lower biomass loss.

\subsection{Anaerobic biological process}

Anaerobic biological treatment has an excellent organic removal efficiency and an economical cost. Organic matter is converted into $\mathrm{CO}_{2}$ and $\mathrm{CH}_{4}$, and sludge during anaerobic biological treatment.

Anaerobic biological technology has been widely applied due to its highly-efficient (Lettinga et al. 2001). Recently, an interest in utilizing up-flow anaerobic sludge bed (UASB) reactors for the treatment of petroleum wastewater has grown because they have a simple design and an easy construction and maintenance (Rastegar et al., 2011). As shown in Table 4, Gasim et al. (2013) indicated that the petroleum refinery wastewater could be successfully treated by the anaerobic treatment process (a UASB reactor) because the highest COD removal of $82 \%$ was observed and more than half of organic compounds could be biodegraded into biogas. In a study performed by Wang et al. (2006) stated that 70\% removal efficiency for COD and $72 \%$ for total oil were obtained by using the up-flow anaerobic sludge bed (UASB) reactor for treatment of heavy oil refinery wastewater containing large amounts of polar organics and demonstrated the potential of this method as an alternative for high-efficiency anaerobic treatment of petroleum wastewater. However, the UASB reactor should be operated under low an organic loading rate and long time during treating petroleum wastewater (Wang et al., 2006). Zou (2015) showed that the ammonia nitrogen $\left(\mathrm{NH}_{3}-\mathrm{N}\right), \mathrm{COD}$ and oil in the heavy oil wastewater were removed by $90.2 \%, 90.8 \%$, and $86.5 \%$, respectively after using the up-flow anaerobic sludge blanket (UASB) reactor and a two-stage biological aerated filter (BAF) system. Nasirpour et al. (2015) used a combined UASB and anaerobic packed-bed biofilm reactor to treat petroleum refinery effluents and found the COD removal efficiency of the system was $81.07 \%$.

\subsection{Aerated lagoons}

The biological processes to treat the petroleum wastewater are usually conducted in activated sludge reactors or in aerated lagoons (Ma et al., 2009; Tellez et al., 2002). Sometimes Aerated lagoons did not achieve the discharge requirements in a treated effluent. They need to huge areas due to their little biomass concentrations ( $\mathrm{Ma}$ et al., 2009).

\subsection{The activated sludge process}

The activated sludge process is more compact but needs to considerable areas for the building of aeration tanks and construction of sludge settlers. Wang et al., (2015) reported that biotransformation of total naphthenic acids (NAs) by the activated sludge system was largely affected by temperature. The average removal efficiency of total naphthenic acids (NAs) in summer $(73 \%)$ was higher than this in winter $(53 \%)$ due to the relatively high microbial biotransformation activities in the activated sludge system in summer. However, this method has too many disadvantages compared with other technologies such as excess sludge production, the need for longer aeration times and high-energy demand (Renou et al., 2008).

\subsection{Biofilm-based reactor}

Biofilm-based reactor systems have high removal efficiencies of suspended solids (Rodgers et al., 2003; Vendramel et al., 2015), flexible and steady operation, ability to endure recalcitrant contaminants, and organic shock loads (Ibrahim et al., 2012; Rodgers et al., 2003) as well as high biomass retention (Gálvez et al., 2003). (Vendramel et al., 2015) showed that the maximum removal of COD and TSS removals were achieved $91 \%$ and $92 \%$, respectively by using anaerobic submerged fixed-bed reactor (ASFBR), which contains corrugated PVC for biofilm attachment. This reactor showed good stability, and its efficiency increased when the organic load of petroleum wastewater increased. The amount of biofilm quantification and important biofilm constituents need more investigation in the reactor operation (Vendramel et al., 2015). Al Hashemi et al. (2015) reported that an average removal efficiency of phenols from the petroleum wastewater was about $98 \%$ by using the sequencing batch reactor system.

\section{Conclusions}

- The petroleum wastewater was treated by different processes such as physical, chemical and biological treatment processes.

- The wastewater from Petroleum industries and refineries mainly contains oil, organic matter and other compounds.

- The petroleum refinery wastewater has hazardous compounds, which adversely affects the ecosystem if they were discharged into the environment.

- Treatment of petroleum wastewater has two stages, firstly, pre-treatment stage to reduce grease, oil and suspended materials. Secondly, an advanced treatment stage to degrade and decrease the pollutants to acceptable discharge values.

- In recent years, many changes in technological approaches for advanced treatment as well as pre-treatment were done except the physical separation due to its efficiency in petroleum wastewater.

- Many different bioreactor designs have been used in treatment of refinery wastewater including batch reactors, fluidized beds and membrane systems.

- Selection among alternative processes is based on capital and operating cost, land availability, operational complexity and standard discharge limits.

- Many technologies aren't used for some recalcitrant and persistent compounds, which aren't adequately eliminated by the biological 
method, because of the poor performance of these processes with these compounds. So, the search for more viable alternatives is very important to solve this problem. Combination of suitable treatment processes can provide effective treatment for these compounds in the petroleum and industrial wastewater.

\section{References}

Abu Hassan M.A., Li T.P. and Noor Z.Z. (2009), Coagulation and flocculation treatment of wastewater in textile industry using chitosan, J. Chem. Nat. Resour. Eng., 4, 43-53.

Abdelwahab O., Amin N.K. and El-Ashtoukhy E-S.Z. (2009), Electrochemical removal of phenol from oil refinery wastewater, J. Hazard Mater., 163, 711-716.

Akpan U.G. and Hameed B.H. (2009), Parameters affecting the photocatalytic degradation of dyes using $\mathrm{TiO}_{2}$-based photocatalysts: a review, J. Hazard. Mater., 170, 520-529.

Al-Rasheed R.A., 2005. Water treatment by heterogeneous photocatalysis an overview. $4^{\text {th }}$ SWCC Acquired Experience Symposium.

Al Zarooni M. and Elshorbagy W. (2006), Characterization and assessment of Al Ruwais refinery wastewater, J. Hazard. Mater., 136, 398-405.

Al Hashemi W., Maraqa M.A., Rao M.V. and Hossain M.M. (2015), Characterization and removal of phenolic compounds from condensate-oil refinery wastewater, Des. Water Treat., 54, 660-671.

Aljuboury D.D.A., Palaniandy P., Abdul Aziz H.B. and Feroz S. (2015a), Treatment of petroleum wastewater using combination of solar photo-two catalyst $\mathrm{TiO}_{2}$ and photoFenton process, J. Environ. Chem. Eng., 3, 1117-1124.

Aljuboury D.D.A., Palaniandy P., Abdul Aziz H.B. and Feroz S. (2015b), New treatment of petroleum wastewater using the combination of solar photo-three catalysts $\mathrm{ZnO}, \mathrm{TiO}_{2}$ and photo-Fenton process, International Journal of Applied Engineering Research, 10(81), 6-14.

Aljuboury D.D.A., Palaniandy P., Abdul Aziz H.B. and Feroz S. (2015c), Evaluating the $\mathrm{TiO}_{2}$ as a solar photocatalyst process by response surface methodology to treat the petroleum waste water, Karbala International Journal of Modern Science, 1, 78-85.

Aljuboury D.D.A., Palaniandy P., Abdul Aziz H.B. and Feroz S. (2015d), Evaluation of the solar photo-Fenton process to treat the petroleum wastewater by response surface methodology (RSM), Earth Sci. J., 1, 45-67.

Aljuboury D.D.A., Palaniandy P., Abdul Aziz H.B. and Feroz S. (2014a), A review on the Fenton process for wastewater treatment, J. Innov. Eng., 2(3):4, 1-21.

Aljuboury D.D.A., Palaniandy P., Abdul Aziz H.B. and Feroz S. (2014b), Organic pollutants removal from petroleum refinery wastewater with nanotitania photo-catalyst and solar irradiation in Sohar oil refinery, J. Innov. Eng., 2(3):5, 1-12.

Aljuboury D.D.A., Palaniandy P., Abdul Aziz H.B. and Feroz S. (2014c), Phenol Degradation of Industrial Wastewater by Photocatalysis, J. Innov. Eng., 2(2): 5, 1-10.

Al-Malack M.H. (2016), Performance of constant-flux immersed UF membrane treating petroleum refinery wastewater, Des. Water Treat., 57(19), 8608-8618.
Altaher H., El Qada E. and Omar W. (2011), Pretreatment of wastewater streams from petroleum/petrochemical industries using coagulation, Adv. Chem. Eng. Sci., 1, 245-251.

Altas L. and Buyukgungor H. (2008), Sulfide removal in petroleum refinery wastewater by chemical precipitation, J. Hazard Mater., 153, 462-469.

Asatekin A. and Mayes A.M. (2009), Oil Industry wastewater treatment with fouling resistant membranes containing amphiphilic comb copolymers, Environ. Sci. Tech., 43, 4487-4492.

Anju S.G., Jyothi K.P., Joseph S., Suguna Y. and Yesodharan E.P. (2012), Ultrasound assisted semiconductor mediated catalytic degradation of organic pollutants in water: Comparative efficacy of $\mathrm{ZnO}, \mathrm{TiO}_{2}$ and $\mathrm{ZnO}-\mathrm{TiO}_{2}$, Res. J. Recent Sci., 1, 191-201.

Alhakimi G., Studnicki L.H. and Al-Ghazali M. (2003), Photocatalytic destruction of potassium hydrogen phthalate using $\mathrm{TiO}_{2}$ and sunlight: application for the treatment of industrial wastewater, J. Photochem. Photobiol. A: Chem., 154, 219-228.

Attiogbe F.K., Glover-Amengor M. and Nyadziehe K.T. (2007), Correlating biochemical and chemical oxygen demand of effluents, a case study of selected industries in Kumasi, Ghana, W. Afr. J. Appl. Ecol., 11, 110-118.

Benyahia F. (2006), Refinery wastewater treatment: a true technological challenge. $7^{\text {th }}$ Annual U.A.E. University Res. Confer. 186-194.

Bustillo-Lecompte C.F., Knight M. and Mehrvar M. (2015), Assessing the performance of $\mathrm{UV} / \mathrm{H}_{2} \mathrm{O}_{2}$ as a pretreatment process in TOC removal of an actual petroleum refinery wastewater and Its inhibitory effects on activated sludge, Canad. J. Chem. Eng., 93, 798-807.

Cavalcanti J.V.F.L., Abreu C.A.M., Carvalho M.N., Sobrinho M.A.M., Benachour M. and Barauna O.S. (2012), Removal of effluent from petrochemical wastewater by adsorption using organo-clay, Petrochemicals, Dr Vivek Patel (Ed.), ISBN: 978953-51-0411-7, InTech.

Chakrabarti S. and Dutta B. (2004), Photocatalytic degradation of model textile dyes in wastewater using $\mathrm{ZnO}$ as semiconductor catalyst, J. Hazard Mater., 112, 269-278.

Chen C., Yoza B.A., Wang Y., Wang P., Li Q.X., Guo S. and Yan G. (2015), Catalytic ozonation of petroleum refinery wastewater utilizing $\mathrm{Mn}-\mathrm{Fe}-\mathrm{Cu} / \mathrm{Al}_{2} \mathrm{O}_{3}$ catalyst, Environ. Sci. Pollut. Res., 22, 5552-5562.

Chu L., Wanga J., Dong J., Liu H. and Sun X. (2012), Treatment of coking wastewater by an advanced Fenton oxidation process using iron powder and hydrogen peroxide, Inter. Chemosphere J., 86, 409-414.

Coelho A., Castro A.V., Dezotti M., Anna G.Jr.L.S. (2006), Treatment of petroleum refinery sourwater by advanced oxidation processes, J. Hazard Mater. B, 137, 178-184.

Correa A.X.R., Erasmo Tiepo N., Somensi C.A., Sperb R.M. and Radetski C.M. (2010), Use of ozone-photocatalytic oxidation $\left(\mathrm{O}_{3} / \mathrm{UV} / \mathrm{TiO}_{2}\right)$ and biological remediation for treatment of produced water from petroleum refineries, J. Environ. Eng., 136, 40-45.

Da Rocha O.R.S., Dantas R.F., Duarte M.M.M.B., Duarte M.M. L. and Da Silva V.L. (2013), Solar photo-Fenton treatment of petroleum extraction wastewater, Des. Water Treat., 51, 28-30, 5785-5791 
Davarnejad R., Pirhadi M., Mohammadi M. and Arpanahzadeh S. (2015), Numerical analysis of petroleum refinery wastewater treatment using electro-Fenton process, Chem. Prod. Process Model, 10(1), 11-16.

Das L., Dutta M., Kumar J. and Basu (2013), Photocatalytic degradation of phenol from industrial effluent using titaniazirconia nanocomposite catalyst, Inter. J. Environ. Sci., 4(3), 415-431.

Demicrci S., Erdogan B. and Oezcicmder R. (1998), Wastewater treatment at the petroleum refinery, Kirikale, Turkey using some coagulants and Turkish clays as coagulant aids, Water Res., 32, 3495-3499.

De Morais J.L. and Zamora P.P. (2005), Use of advanced oxidation processes to improve the biodegradability of mature landfill leachates, J. Hazard. Mater., 123, 181-186.

Deng Y. and Englehardt J.D. (2006), Treatment of landfill leachate by the Fenton process, Water Res., 40, 3683-3694.

Dialynas E., Mantzavinos D. and Diamadopoulos E. (2008), Advanced treatment of the reverse osmosis concentrate produced during reclamation of municipal wastewater, Water Res., 42(18), 4603-4608.

Diyauddeen B.H., Wan M.A., Wan D. and Abdul Aziz A.R. (2011), Treatment technologies for petroleum refinery effluents: $A$ review, Process Saf. Environ. Protec., 89, 95-105.

Dincer A.R., Karakaya N., Gunes E. and Gunes Y. (2008), Removal of $C O D$ from oil recovery industry wastewater by the Advanced Oxidation Processes (AOP) based on $\mathrm{H}_{2} \mathrm{O}_{2}, \mathrm{Glob}$. N. J., 10, 31-38.

Doggett T., Rascoe A., 2009. Global Energy Demand.

Ehrampoush M.H., Moussavi G.H.R., Ghaneian M.T., Rahimi S. and Ahmadian M. (2011), Removal of methylene blue dye from textile simulated sample using tubular reactor and $\mathrm{TiO}_{2} / \mathrm{UV}-\mathrm{C}$ photocatalytic process, Iran. J. Environ. Health. Sci. Eng., 8, 35-40.

El-Naas M.H., Al-Zuhair S. and Alhaija M.A. (2009a), Reduction of COD in refinery wastewater through adsorption on Date-Pit activated carbon, J. Hazard. Mater., 173, 750-757.

El-Naas M.H., Al-Zuhair S., Al-Lobaney A. and Makhlouf S. (2009b), Assessment of electro-coagulation for the treatment of petroleum refinery wastewater, J. Environ. Manage., 91, 180-185.

El-Ashtoukhy E-S.Z., El-Taweel Y.A., Abdelwahab O. and Nassef E.M. (2013), Treatment of petrochemical wastewater containing phenolic compounds by electrocoagulation using a fixed bed electrochemical reactor, Int. J. Electrochem. Sci., 8, 1534-1550.

Elmolla E.S. (2015), DAF-Treated Lube Oil Wastewater (DTLOWW) Treatment: Performance of Bench Scale and Pilot Scale Fenton Process, J Civil Environ Eng., 5, 2, 1-5.

Farajnezhad H. and Gharbani P. (2012), Coagulation treatment of wastewater in petroleum industry using poly aluminum chloride and ferric chloride, Inter. J. Res. Review. Appl. Sci., 13, 306-310.

Fujishima A., Zhang X. and Tryk D.A. (2008), $\mathrm{TiO}_{2}$ photocatalysis and related surface phenomena, Surf. Sci. Rep., 63, 515-582.

Galil N., Rebhun M. and Brayer Y. (1988), Disturbances and inhibition in biological treatment of wastewater from an integrated refinery, Water Sci. Tech., 20, 21-29.

Galvez J.M., Gvmez M.A., Hontoria E. and Gonzales-Lopez J. (2003), Influence of hydraulic loading and air flow rate on urban wastewater nitrogen removal with a submerged fixedfilm reactor, J Hazard Mater., 101, 219-229.

Gasim H.A., Kutty S.R.M., Hasnain-Isa M. and Alemu L.T. (2013), Optimization of anaerobic treatment of petroleum refinery wastewater using artificial neural networks, Res. J. Appl. Sci. Eng. Tech., 6, 2077-2082.

Gaya U.I. and Abdullah A. (2008), Heterogeneous photocatalytic degradation of organic contaminants over titanium dioxide: a review of fundamentals, progress and problems, J. Photochem. Photobiol. C: Photochem. Rev., 9, 1-12.

Gogate P.R. and Pandit A.B. (2004), A review of imperative technologies for wastewater treatment II: hybrid methods, Adv. Environ. Res., 8, 553-597.

Harry, M.F., 1995. Industrial Pollution Handbook. McGraw Hill. Inc., New York.

Hasan D.U.B., Abdul Aziz A.R. and Daud W.M.A.W. (2012), Oxidative mineralisation of petroleum refinery effluent using Fenton-like process, Chem. Eng. Res. Des., 90(2), 298-307.

Hamoda M.F. and Al-Ghusain I.A. (1998), Analysis of organic removal rates in the aerated submerged fixed film process, Water Sci. Technol., 38, 213-221.

Hermosilla D., Cortijo M. and Huang C.P. (2009), Optimizing the treatment of landfill leachate by conventional Fenton and photo-Fenton processes, Sci. T. Environ., 407, 3473-3481.

Hu G., Li J. and Hou H. (2015), A combination of solvent extraction and freeze thaw for oil recovery from petroleum refinery wastewater treatment pond sludge, J. Hazard Mater., 283, 832-840.

Hua F.L., Tsang Y.F., Wang Y.J., Chan S.Y., Chua H. and Sin S.N. (2007), Performance study of ceramic microfiltration membrane for oily wastewater treatment, Chem. Eng. J., 128, 169-175.

Huang Yao-Hui, Huang Yu-Jen, Tsai Hung-Chih and Chen Hung-Ta (2010), Degradation of phenol using low concentration of ferric ions by the photo-Fenton process, J. Taiwan Ins. Chem. Eng., 41, 6, 699-704.

Huang C.-R. and Shu H.-Y. (1995), The reaction kinetics, decomposition pathways and intermediate formations of phenol in ozonation, $\mathrm{UV} / \mathrm{O}_{3}$, and $\mathrm{UV} / \mathrm{H}_{2} \mathrm{O}_{2}$ processes, J. Hazard. Mater., 41, 47-64.

Ibrahim H.T., Qiang H., Al-Rekabi W.S. and Qiqi Y. (2012), Improvements in biofilm processes for wastewater treatment, Pakistan J Nutr., 11, 610-636.

Jafarzadeh M.T., Nikkhoo Y., Khoshgard A. and Aslani R. (2011), Treatment of petrochemical effluent by electro-coagulation method, Inter. Confer. Chem. Environ. Bio. Sci., 350-352.

Jyoti J., Alka D. and Kumar S.J. (2013), Application of membrane bio-reactor in waste-water treatment: a review, Inter. J. Chemist. Chem. Eng., 3, 115-122.

Jou Chih-Ju G. and Huang Guo-Chiang (2003), A pilot study for oil refinery wastewater treatment using a fixed film bioreactor, Adv. Environ. Res., 7, 463-469.

Jain R. and Shrivastava M. (2008), Photocatalytic removal of hazardous dye cyanosine from industrial waste using titanium dioxide, J. Hazard. Mater., 152, 216-220.

Kavitha V. and Palanivelu K. (2004), The role of ferrous ion in Fenton and photo-Fenton processes for the degradation of phenol, Chemosphere, 55, 1235-1243.

Khana W.Z., Najeeb I., Tuiyebayeva M. and Makhtayev Z. (2015), Refinery wastewater degradation with titanium dioxide, zinc 
oxide, and hydrogen peroxide in a photocatalytic reactor, Pro. S. Environ. Protect., 9, 479-486.

Kim J.L., Leea H. and Lee C. (2012), Synergistic effects of $\mathrm{TiO}_{2}$ photocatalysis in combi-nation with Fenton-like reactions on oxidation of organic compounds at circumneutral $\mathrm{pH}, \mathrm{Appl}$. Catal. B: Environ., 115, 219-224.

Krutzler T. and Bauer R. (1999), Optimization of a photo-Fenton prototype reactor, Chemosphere, 38, 2517-2532.

Kulkarni S.J. and Goswami A.K. (2014), Applications and advancements in treatment of waste water by membrane technology: A review, Inter. J. Eng. Sci. Res. Tech., 3, 446-450.

Kulkarni S.J. and Goswami A.K. (2013), Adsorption studies for organic matter removal from wastewater by using bagasse Flyash in Batch and Column Operations, Inter. J. Sci. Res., 2,180-183.

Lettinga G., Rebac S. and Zeeman G. (2001), Challenge of psychrophilic anaerobic wastewater treatment, Trends Biotechnol., 19, 363-370.

Lathasree S., Rao N., Sivashankar B., Sadasivam V. and Rengaraj K. (2004), Heterogeneous photo catalytic mineralization of phenols in aqueous solutions, J. Mol. Catal. A: Chem., 223, 101-105.

Lawrence K., Wang Yung-Tse Hung, Howard H. and Lo Y.C. (2007), Hazardous industrial waste treatment. Taylor and Francis. New York, USA.

Lema J.M., Mendez R. and Blazquez R. (1998), Characteristics of landfill leachates and alternatives for their treatment: a review, Air and soil pollution, 40, 223-250.

Li Y., Yan L., Xiang C. and Hong L.J. (2006), Treatment of oily wastewater by organic-inorganic composite tubular ultrafiltration (UF) membranes, Des., 196, 76-83.

Lin, H.T., 2005. Photocatalysis in a novel semiconducting optical fiber monolithic reactor for wastewater treatment. PhD Thesis, Louisiana State University.

Lucas M.S. and Peres J.A. (2009), Removal of COD from olive mill wastewater by Fenton's reagent: kinetic study, J. Hazard. Mater., 168, 1253-1259.

Ma F., Guo J.-B., Zhao L.-J., Chang C.-C. and Cui D. (2009), Application of bio-augmentation to improve the activate sludge system into the contact oxidation system treatment petrochemical wastewater, Bioresource Tech., 100, 597-602.

Malamis S., Katsou E., Di Fabio S., Frison N., Cecchi F. and Fatone F. (2015), Treatment of petrochemical wastewater by employing membrane bioreactors: a case study of effluents discharged to a sensitive water recipient, Des. Water Treat. 53(12), 3397-3406.

Manyuchi M.M. and Ketiwa E. (2013), Distillery effluent treatment using membrane bioreactor technology utilising pseudomonas fluorescens, Inter. J. Sci. Eng. Tech., 2, 1252-1254

Mrayyana B. and Battikhi M.N. (2005), Biodegradation of total organic carbons (TOC) in Jordanian petroleum sludge, J. Hazard. Mater., 120, 127-134.

Masomboon N., Chen C.W., Anotai J. and Lu M.C. (2010), A statistical experimental design to determine o-toluidine degradation by the photo-Fenton process, Chem. Eng. J., 159, 116-122.

Melamane X.L., Strong P.J. and Burgess J.E. (2007), Treatment of wine distillery wastewater: A review with emphasis on anaerobic membrane reactors, S. Afr. J. Enol. Vitic., 28, 25-36.
Moslehyani A., Ismail F., Othman M.H.D. and Matsuura T. (2015), Design and performance study of hybrid photocatalytic reactor-PVDF/MWCNT nanocomposite membrane system for treatment of petroleum refinery wastewater, Des., 363, 99-111.

Nasirpour N., Mousavi S. and Shojaosadati S. (2015), Biodegradation potential of hydrocarbons in petroleum refinery effluents using a continuous anaerobic-aerobic hybrid system, Korean J. Chem. Eng., 32, 874-881.

Nogueira R.F.P., Trovo A.G. and Paterlini W.C. (2004), Evaluation of the combined solar $\mathrm{TiO}_{2} /$ photo-Fenton process using multivariate analysis, Water Sci. Technol., 49, 195-200.

Paz D.S., Foletto E.L., Bertuol D.A., Jahn S.L., Collazzo G.C., Silva S.S., Chiavone-Filho O. and Nascimento C.A.O. (2013), $\mathrm{CuO} / \mathrm{ZnO}$ coupled oxide films obtained by the electrodeposition technique and its photocalytic activity in phenol degradation under solar irradiation, Water Sci. Tech., 68, 1031-1036

Pardeshi S.K. and Patil A.B. (2008), A simple route for photocatalytic degradation of phenol in aqueous zinc oxide suspension using solar energy, Solar Energy, 82, 700-705.

Pera-Titus M., Garcia-Molina V., Banos M., Gimenez J. and Esplugas S. (2004), Degradation of chlorophenols by means of advanced oxidation processes: a general review, Appl. Catal. $B, 47,219-256$

Parilti N.B. (2010), Treatment of a petrochemical industry wastewater by a solar oxidation process using the Box-Wilson experimental design method, Ekoloji, 19(77), 9-15.

Pignatello J.J., Oliveros E. and Mackay A. (2006), Advanced oxidation processes for organic contaminant destruction based on the Fenton reaction and related chemistry, Crit. Rev. Environ. Sci. Technol., 36, 1-84.

Philippopoulos C.J. and Poulopoulos S.G. (2003), Photo-assisted oxidation of an oily wastewater using hydrogen peroxide, $J$. Hazard. Mater, 98, 201-210.

Rahman M.M. and Al-Malack M.H. (2006), Performance of a cross flow membrane bioreactor (CF-MBR) when treating refinery wastewater, Des., 191, 16-26.

Rajeshwar K., Osugi M.E., Chanmanee W., Chenthamarakshan C.R., Zanoni M.V.B., Kajitvichyanukul P. and Krishnan-Ayer R. (2008), Heterogeneous photocatalytic treatment of organic dyes in air and aqueous media, J. Photochem. Photobiol. C: Photochem. Rev., 9, 171-192.

Ramteke L.P. and Gogate P.R. (2015), Treatment of toluene, benzene, naphthaleneand xylene (BTNXs) containing wastewater using improved biological oxidation with pretreatment using Fenton/ultrasound based processes, J. Indus. Eng. Chem., 28, 247-260.

Rasheed Q.J., Pandian K. and Muthukumar K. (2011), Treatment of petroleum refinery wastewater by ultrasound-dispersed nanoscale zero-valent iron particles, Ultrason. Sonochem., 18, 1138-1142.

Rastegar S.O., Mousavi S.M., Shojaosadati S.A. and Sheibani S. (2011), Optimization of petroleum refinery effluent treatment in a UASB reactor using response surface methodology, J. Hazard Mater., 197, 26-32.

Razavi S.M.R. and Miri T. (2015), A real petroleum refinery wastewater treatment using hollow fiber membrane bioreactor (HF-MBR), J. Water Process Eng., 8, 136-141. 
Renou S., Givaudan J.G., Poulain S., Dirassouyan F. and Moulin P. (2008), Landfill leachate treatment: review and opportunity, J. Hazard. Mater., 150, 468-493.

Renault F., Sancey B., Badot P.-M. and Crini G. (2009), Chitosan for coagulation/flocculation processes, an eco-friendly approach, Eur. Polym. J., 45, 1337-1348.

Rodgers M., Zhan X-M and Gallagher B. (2003), A pilot plant study using a vertically moving biofilm process to treat municipal wastewater, Bioresource Technol., 89, 139-143.

Rossiter O., Rochaa S., Renato D.F., Marta M.M. and Duarte B. (2013), Solar photo-Fenton treatment of petroleum extraction wastewater, J. Des. Water Treat., 51, 5785-5791.

Rubio-Clemente A., Chica E. and Penuela G.A. (2015), Petrochemical wastewater treatment by photo-Fenton process, Water Air Soil Pollut., 226, 61-79.

Saber A., Hasheminejad H., Taebi A. and Ghaffari G. (2014), Optimization of Fenton-based treatment of petroleum refinery wastewater with scrap iron using response surface methodology, Appl. Water Sci., 4, 283-290.

Satyawali Y. and Balakrishnan M. (2008), Wastewater treatment in molasses-based alcohol distilleries for COD and color removal: a review, J. Environ. Manage., 86, 481-497.

Singh C., Chaudhary R. and Gandhi K. (2013), Preliminary study on optimization of $\mathrm{pH}$, oxidant and catalyst dose for high COD content: solar parabolic trough collector, Iran. J. Environ. $\mathrm{H}$. Sci. Eng., 10, 2-10.

Saien J. and Nejati H. (2007), Enhanced photocatalytic degradation of pollutants in petroleum refinery wastewater under mild conditions, J. Hazard. Mater., 148, 491-495.

Seif, H., 2001. Physical treatment of petrochemical wastewater, $6^{\text {th }}$ Inter. Water Tech. Confer. IWTC, 598-607.

Shahrezaei F., Mansouri Y., Zinatizadeh A.A.L. and Akhbari A. (2012), Process modeling and kinetic evaluation of petroleum refinery wastewater treatment in a photocatalytic reactor using $\mathrm{TiO}_{2}$ nanoparticles, Powder Tech., 221, 203-212.

Shahrezaei F., Pakravan P., Hemati A.A., Pirsaheb M. and Mansouri A.M. (2015), Preparation of multi-walled carbon nanotubedoped $\mathrm{TiO}_{2}$ composite and its application in petroleum refinery wastewater treatment, Des. Water Treat., 13, 1-10.

Shariati S.R.P., Bonakdarpour B., Zare N. and Ashtiani F.Z. (2011), The effect of hydraulic retention time on the performance and fouling characteristics of membrane sequencing batch reactors used for the treatment of synthetic petroleum refinery wastewater, Biores. Tech., 102, 7692-7699.

Shokrollahzadeh S., Azizmohseni F., Golmohammad F., Shokouhi H. and Khademhaghighat F. (2008), Biodegradation potential and bacterial diversity of a petrochemical wastewater treatment plant in Iran, Biores. Tech., 99, 6127-6133.

Silva S.S., Chiavone-Filho O., Neto E.L.B. and Foletto E.L. (2015), Oil removal from produced water by conjugation of flotation and photo-Fenton processes, J. Environ. Manage., 147, 257-263.

Squillance P.J., Zogorski J.S., Wilber W.G. and Price C.V. (1996), Preliminary assessment of the occurrence and possible sources of MTBE in groundwater in the United States, Environ. Sci. Technol., 30, 1721-1730

Stepnowski P., Siedlecka E.M., Behrend P. and Jastorff B. (2002), Enhanced photo-degradation of contaminants in petroleum refinery wastewater, Water Res., 36, 2167-2172.
Sumit P. and Vimala Y. (2012), Bioremediation and decolorization of Distillery effluent by novel Microbial Consortium, Eur. J. Exp. Bio., 2, 496-504.

Sun Y., Zhang Y. and Quan X. (2008), Treatment of petroleum refinery wastewater by microwave-assisted catalytic wet air oxidation under low temperature and low pressure, Separ. Purific. Tech., 62, 565-570.

Tellez G.T., Nirmalakhandan N. and Gardea-Torresdey J.L. (2002), Performance evaluation of an activated sludge system for removing petroleum hydrocarbons from oilfield produced water, Adv. Environ Res., 6, 455-470.

Tengrui L., Al-Harbawi A.F., Bo L.M. and Jun Z. (2007), Characteristics of nitrogen removal from old landfill leachate by sequencing batch biofilm reactor, J. Appl. Sci., 4, 211-214.

Tony M.A., Patrick J. and Purcell Yaqian Z. (2012), Oil refinery wastewater treatment using physicochemical, Fenton and Photo-Fenton oxidation processes, J. Environ. Sci. Heal. A., 47, 435-40.

Tony M.A., Zhao Y.Q., Purcell P.J. and El-Sherbiny M.F. (2009), Evaluating the photo-catalytic application of Fenton's reagent augmented with $\mathrm{TiO}_{2}$ and $\mathrm{ZnO}$ for the mineralization of an oilwater emulsion, J. Environ. Sci. Health A, 44(5), 488-493.

Torrades J., Garcia M., Garcia H.JA, Domenech X. and Peral J. (2004), Decolorization and mineralization of commercial reactive dyes under solar light assisted photo-Fenton conditions, Sol. Energy, 77, 573-581.

Topare N.S., Joy M., Joshi R.R., Jadhav P.B. and Kshirsagar L.K. (2015), Treatment of petroleum industry wastewater using $\mathrm{TiO}_{2}$ /UV photocatalytic process, J. Indian Chem. Soc., 92, 219-222.

Vendramel S., Bassin J.P., Dezotti M. and Sant' Anna Jr G.L. (2015), Treatment of petroleum refinery wastewater containing heavily polluting substances in an aerobic submerged fixedbed reactor, Environ. Tech., 36, 2052-205.

Wake H. (2005), Oil refineries: a review of their ecological impacts on the aquatic environment, Estuar. Coast Shelf Sci., 62, 131-140.

Wagner M. and Nicell J.A. (2001), Peroxid ase-catalyzed removal of phenols from a petroleum refinery wastewater, Water Sci. Tech., 43, 253-260.

Wang Y., Wang Q., Min L, Yingnan Y., Wei H., Guangxu Y. and Shaohui G. (2016), An alternative anaerobic treatment process for treatment of heavy oil refinery wastewater containing polar organics, Biochem. Eng. J., 105, 44-51.

Wang B., Yi W., Yingxin G., Guomao Z., Min Y., Song W. and Jianying H. (2015), Occurrences and behaviors of Naphthenic Acids in a petroleum refinery wastewater treatment plant, Environ. Sci. Technol., 49, 5796-5804.

Wang K.-H., Hsieh Y.-H., Ko R.-C. and Chang C.-C. (1999), Photocatalytic degradation of wastewater from manufactured fiber by titanium dioxide suspensions in aqueous solution, Environ. Int., 25, 671-676.

Wiszniowski J., Robert D., Surmacz-Gorska J., Miksch K. and Weber J.V. (2006), Landfill leachate treatment methods: A review, Environ. Chem. Letter., 4(1), 51-61.

Xu X. and Zhu X. (2004), Treatment of refectory oily wastewater by electro-coagulation process, Chemosphere, 56, 889-894.

Yavuz Y., Koparal A.S. and Ogutveren U.B. (2010), Treatment of petroleum refinery wastewater by electrochemical methods, Des., 258, 201-205. 
Yeh C.K.J., Hsu C.Y., Chiu C.H. and Huang K.L (2008), Reaction efficiencies and rate constants for the goethite-catalyzed Fenton-like reaction of NAPL-form aromatic hydrocarbons and chloroethylenes, J. Hazard. Mater., 151, 562-569.

Yang X., 2008. Sol-gel synthesized nanomaterials for environmental applications. PhD Thesis, Kansas State University.

Yuliwati E., Ismail A.F., Matsuura T., Kassim M.A. and Abdullah M.S. (2011), Effect of modified PVDF hollow fiber submerged ultrafiltration membrane for refinery wastewater treatment, Des., 283, 214-220.

Zenga Y., Yang C., Zhang J. and Pu W. (2007), Feasibility investigation of oily wastewater treatment by combination of zinc and PAM in coagulation/flocculation, J. Hazard. Mater., 147, 991-96.

Zhang J., Sun X. and Wang C. (2003), Treatment of oily wastewater produced from refinery processes using flocculation and ceramic membrane filtration, Separ. Purific. Tech., 32, 93-98.

Zhao X., Wang Y., Ye Z., Borthwick A.G.L. and Ni J. (2006), Oil field wastewater treatment in Biological Aerated Filter by immobilized microorganisms, Process Biochem., 41, 1475-1483.

Zou X.L. (2015), Treatment of heavy oil wastewater by UASB-BAFs using the combination of yeast and bacteria, Environ, Tech., 36(18), 2381-2389.

Zarei M. A., Khataee M., Fathinia F., Seyyednajafi H. and Ranjbar (2012), Combination of nanophotocatalysis with electroFenton-like process in the removal of phenol from aqueous solution: GC analysis and response surface approach, Int. J. Ind. Chem., 3(1), 27-28. 